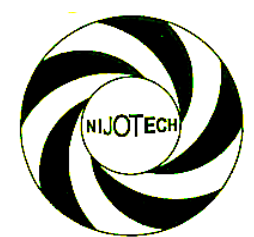

Nigerian Journal of Technology (NIJOTECH)

Vol. 36, No. 2, April 2017, pp. 482 - 495

Copyright@ Faculty of Engineering, University of Nigeria, Nsukka,

Print ISSN: 0331-8443, Electronic ISSN: 2467-8821

www.nijotech.com

http://dx.doi.org/10.4314/njt.v36i2.23

\title{
OPTIMIZATION OF COAGULATION-FLOCCULATION PROCESS FOR COLOUR REMOVAL FROM AZO DYE USING NATURAL POLYMERS: RESPONSE SURFACE METHODOLOGICAL APPROACH
}

\author{
I. A. Obiora-Okafo',* and O. D. Onukwuli²

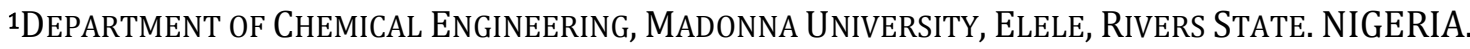 \\ 2Department of Chemical EngineEring, NNAmdi AZikiwe University, AWKa, ANAmbra State. NiGERia \\ E-mail addresses:1ifyobioraokafo@yahoo.com, ${ }^{2}$ onukwuliod@yahoo.com
}

\begin{abstract}
The ability of organic polymer rich coagulants for colour removal from acid dye was studied. An improved method for the extraction of the active coagulant agent from the seeds was employed. The effects of four variables including $\mathrm{pH}$, coagulant dosage, dye concentration and time were analyzed. Response surface methodology (RSM) using face-centered central composite design (FCCD) was used to optimize the four variables. Increase in the colour removal efficiency was higher in acidic solution pH. Accurate control of coagulant dosages gave optimum destabilization of charged particles and re-stabilization occurred at above $800 \mathrm{mg} / \mathrm{L}$ dosages. Polymer performances were measured through time-dependent decrease in particle concentrations following aggregates growth. The verification experiment agreed with the predicted values having less than 4\% standard error. Overlay contour plot was used to establish an optimum condition for the multiple responses studied. The response surface approach was appropriate for optimizing the coagulation-flocculation process while minimizing the number of experiments. Coagulants studied should be considered as an alternative for conventional coagulants that are widely used in dye wastewater treatment plants.
\end{abstract}

Keywords: Coagulation-flocculation, Azocarmine G, multiple response optimization, response surface design, colour removal, natural organic polymers.

\section{INTRODUCTION}

Contaminations of environment by wastewater discharge have caused environmental, social, economic and public health problems [1-2]. Dye-containing wastewaters are contaminants because of their highly toxic characteristics [3]. Presently, about 10,000 different commercial dyes and pigments are available and over $7.11 \times 10^{7} \mathrm{~kg} / \mathrm{yr}$ is produced worldwide [4]. Dye production industries (such as textile, rubber, pulp, paper, plastic, cosmetics, food, pharmaceutical, leather tanning, printing, medicine, etc.) generate wastewater characteristically high in colour, organic and inorganic contents. Dye wastewaters have to be treated to accord with discharging limit [5].

The methods used for contaminant removals from dye wastewater can be divided into three main categories; physical, chemical and biological. Physical treatments such as precipitation, ion exchange, membrane filtration, irradiation, ozonation and adsorption are widely used techniques. Physico-chemical treatment methods are coagulation-flocculation, precipitation, photo-catalysis, oxidation and chemical sludge oxidation. Lastly, biological treatment techniques used are aerobic degradation, anaerobic degradation, and living/dead microbial biomass [6]. Coagulation-flocculation is an already established process for contaminant removal from most wastewaters ranging from wastewater containing: biochemical oxygen demand; BOD [7], colour [8], dissolved organic carbon; DOC [9], turbidity [10], chemical oxygen demand; COD [11], grease and oil [12], total suspended solids; TSS [7], heavy metals [13-14]. Coagulation-flocculation is an efficient unit process used for colour removal from industrial wastewater due to its efficiency and simplicity to operate [12].

Typical coagulants are inorganic salt such as $\mathrm{Al}\left(\mathrm{SO}_{4}\right)_{3}$ or $\mathrm{FeCl}_{3}$, as well as synthetic organic polymer [15]. Although these chemicals are rather effective in removing dyes and suspended matters from the aqueous solution, several disadvantages have recently arisen, such as their impact on human diseases like Alzheimer's caused by inorganic salts [16] and neurotoxin and carcinogenic effects [17] caused by acrylic amide or poly acryl amides. To solve these problems, natural coagulants extracted

* Corresponding author tel: +234-803-823-8902. 
from plants have been in use. Natural polymer coagulants are of emerging trend by many researchers because of their abundant source, low price, environmental friendliness, multifunctionality; they do not alter treated water $\mathrm{pH}$ and biodegradability in water. In this study, the active coagulant agents extracted from the seeds of cowpea (Vigna unguiculata), fluted pumpkin (Telfairia occidentalis), black timber (Brachystegia eurycoma), Bambara nut (Vigna subterranean), and horse radish (Moringa oleifera) were used for decolourization of Azocarmine G dye. The seeds extract are characterized to be a soluble cationic protein and possess the ability to act as a natural polymer coagulant [15, 19-23].

We used RSM to develop a mathematical correlation between $\mathrm{pH}$, coagulant dosage, dye concentration and time for the colour removal from the dye containing wastewater. A face-centered central composite design (FCCD), a very efficient design tool for fitting the secondorder models [24] was selected and design-expert (version 9. 0. 1.0) software achieved this purpose. Design-expert also demonstrated the analysis of variance (ANOVA), 3D surface plot, numerical optimization and multiple response optimization (MRO) using overlay contour plot.

The present work explores the potentials and effectiveness of using active coagulant proteins obtained from the seeds for decolourization of acid red 101 (Azocarmine G) in aqueous solution. Newer approach of extracting active coagulant agent is adopted in the coagulation-flocculation process. In addition, choices of coagulant and dye ionic nature are necessary for high efficiency performances.

\section{MATERIALS AND METHODS}

\subsection{Materials Collection and Preparation of Natural Coagulants Seed Powder}

Sample 1: Vigna unguiculata (Cowpea)

Sample 2: Telfairia occidentalis (Fluted pumpkin)

Sample 3: Brachystegia eurycoma (Black Timber)

Sample 4: Vigna subterranean (Bambara nut)

Sample 5: Moringa oleifera (Horse radish)

Coagulant precursors were prepared as follows:

Dried seeds of Vigna unguiculata were purchased from local market of Enugu city. Matured seeds showing no signs of discolouration were used.

Matured pods containing Telfairia occidentalis seeds were purchased from local market of Enugu city. The seeds were removed from the pod, dried under sun for days, and the external shells were removed. Matured seeds showing no signs of discolouration, softening or extreme desiccation were selected.
Wet seeds of Brachystegia eurycoma were purchased from local market of Enugu city. Matured seeds showing no signs of discolouration were used. The seeds were dehulled and sun dried.

Powder of Vigna subterranean was bought from local market of Enugu city.

Moringa oleifera seed pods were purchased from local market of Enugu city. Matured seeds showing no signs of discolouration, softening or extreme desiccation were used. The seeds were de-hulled and sun dried.

The dry seeds of the five samples were grounded to fine powder $(63-600 \mu \mathrm{m})$ using an ordinary food processor (Model BL 1012, Khind) to achieve solubilization of active ingredients. The seed powders were then ready for extraction of the active components.

\subsection{Extraction of Active Component}

The active proteins from coagulants were extracted by adding $2 \mathrm{~g}$ of powdered samples to $100 \mathrm{~mL}$ distilled water. Magnetic stirrer (Model 78HW-1, U-Clear England) stirred the stock solution vigorously for $20 \mathrm{~min}$ at room temperature to promote water extraction of the coagulant proteins. Filter paper (What. no. 42, 125mm diameter) filtered the suspension. The filtrate portions were used as coagulant at required dosages. Fresh solutions were prepared daily and kept refrigerated to prevent any ageing effects (such as change in $\mathrm{pH}$, viscosity and coagulation activity). Before each experiment, solutions were shaken vigorously and used immediately for each sequence of experiment.

\subsection{Characterization of the Coagulants}

Yield, bulk density, moisture content, ash content, protein content, fat content, carbohydrate content and fibre content of the seed powders were determined by the standard official methods of analysis of the A.O.A.C [25].

\subsection{Buffer Solution}

All assays were done in a pH-stable medium. Buffer solutions ( $\mathrm{pH} \mathrm{2,} \mathrm{4,} \mathrm{6,} \mathrm{7,} \mathrm{8and} \mathrm{10)} \mathrm{were} \mathrm{prepared} \mathrm{by} \mathrm{the}$ standards established according to the National bureau of standards (NBS) and were standardized using a digital $\mathrm{pH}$ meter. All reagents used were of analytical purity grade.

\subsection{Dye Preparation and Absorption Spectrum Determination}

Acid Red 101 (water soluble dye) was provided by May \& baker England with molecular structure as shown in Fig. 1. The characteristics of the dye are summarized in Table 1. Dye with commercial purity was used without further purification. The absorption spectrum of the dye 
was obtained by dissolving $1000 \mathrm{mg} / \mathrm{L}$ of AR 101 in distilled water. A sample of the solution was scanned against the blank of distilled water in the range of 250 $850 \mathrm{~nm}$ using UV-Vis spectrophotometer (Shimadzu, Model UV - 1800). Stock solution of $1000 \mathrm{mg} / \mathrm{L}$ of dye was prepared by dissolving accurately weighed amounts of AR 101 in separate doses of $1 \mathrm{~L}$ distilled water. The desirable experimental concentrations of $10-120 \mathrm{mg} / \mathrm{L}$ were prepared by diluting the stock solution when necessary. The wavelength of maximum absorbance $\left(\lambda_{\max }\right)$ and calibration curve at $\lambda_{\max }$ were determined.

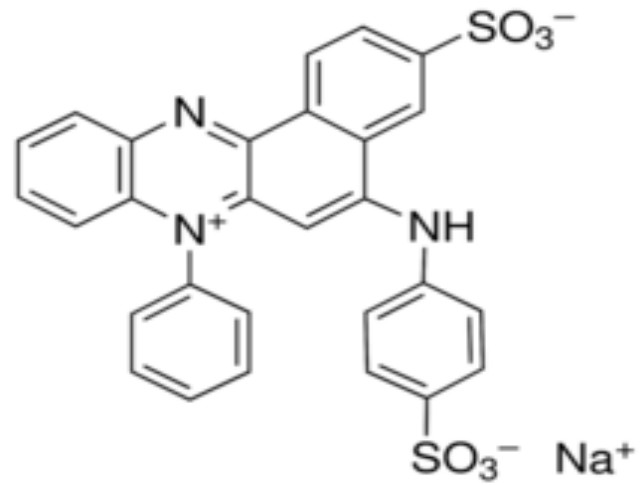

Figure 1: Structure of Azocarmine G (AR 101).

Table 1: Physical properties of Azocarmine $G$.

\begin{tabular}{ll}
\hline Property & Data \\
\hline Chemical name & Azocarmine G \\
Chemical formula & $\mathrm{C}_{28} \mathrm{H}_{18} \mathrm{~N}_{3} \mathrm{NaO}_{6} \mathrm{~S}_{2}$ \\
C.I number & 50085 \\
C.I name & Acid Red 101. \\
Class & Quinone - imine \\
Molecular Weight & 579.58 \\
CAS number & $25641-18-3$ \\
EC number & $247-157-3$ \\
UV/Visible Absorbance & Max. (Water): $510+$ \\
& 6 nm. \\
\hline
\end{tabular}

\subsection{Coagulation Studies}

A conventional jar test apparatus (Phipps and Bird, VA, USA) equipped with six beakers of $1 \mathrm{~L}$ capacity and six paddle stirrers was used to perform the coagulationflocculation experiment. The jar test was conducted to evaluate the performance of the coagulants agent extracted based on standard methods [23, 26]. The coagulation-flocculation procedure involved 4minutes of rapid mixing at $100 \mathrm{rpm}$. The mixing speed was reduced to $40 \mathrm{rpm}$ for another 25 minutes. All the suspensions were left for settling (60-540 minutes). The procedure involved $4 \mathrm{~min}$ of rapid mixing at $100 \mathrm{rpm}$. The mixing speed was reduced to $40 \mathrm{rpm}$ for another 25 minutes. All the suspensions were left for settling (60 - 540 minutes). Supernatant samples were withdrawn after settling for absorbance analysis using UV-Vis spectrophotometer at maximum absorbance of $516 \mathrm{~nm}$. Colour removal was analyzed as a decrease in optical density measurement at
$516 \mathrm{~nm}$. Removal efficiency was obtained according to Eq. 1:

$$
\text { Colour removal }(\%)=\left(\frac{C_{0}-C}{C_{0}}\right) \times 100
$$

In (1), $C_{0}$ and Care the initial and final colour concentration (mg/L) in dye solutions before and after coagulation-flocculation treatment, respectively.

\subsubsection{Decolourization determination}

Colour measurement was determined with standard dilution multiple method and by comparing absorbance to a calibration curve. Decolourization of AR 101 was determined by monitoring the decrease in the absorbance peak at the maximum wavelength of $516 \mathrm{~nm}$. Dye concentration of the supernatant (from coagulation experiment) was measured using UV-Vis spectrophotometer (Shimadzu, model 1800). The study was conducted by varying few experimental parameters including $\mathrm{pH}$, coagulants dosages, dye concentrations and time. The $\mathrm{pH}$ was adjusted to the desired value using $0.1 \mathrm{M} \mathrm{HCI}$ and $0.1 \mathrm{M} \mathrm{NaOH}$.

\subsection{Experimental Design and Data Analysis}

Central composite design (CCD), a very efficient design tool for fitting the second-order models (Montgomery 2001), was used in the experimental design. The CCD introduced by Box Wilson in 1951, is well suited for fitting quadratic surface, which usually works well for the process optimization. In this research, the facecentered experimental plan was implemented as a CCD. A CCD is made face-centered by the choice of $\alpha=1$ [27]. Face-centered design is having the position of the star points at the face of the cube portion on the design [24]. The face-centered option ensures that the axial runs will not be any more extreme than the factorial portion. The independent variables selected for this study were $\mathrm{pH}$ (A), coagulant dosage (B), dye concentration (C), and time (D). A $2^{4}$ two-level factorial for four independent variables consisting of 16 factorial points coded to the usual \pm notation, 8 axial points and 6 replicate at centre point where conducted, given a total of 30 experiments for each response. Mathematically, Eq. (2) was used to determine the total number of runs performed. The total number of experiments, $\mathrm{N}$ with $\mathrm{k}$ factors is:

$$
N=2^{K}+2 K+n
$$

Where $\mathrm{k}$ is the number of factors and $\mathrm{n}$ is centre points. The experimental design table is presented in Table 2. For statistical calculations, the variables $\mathrm{Z}_{\mathrm{i}}$ (the real value of an independent variable) were coded as $\mathrm{X}_{\mathrm{i}}$ (dimensionless value of an independent variable) according to Eq. (3):

$$
X_{i}=\frac{Z_{i}-Z_{i}^{*}}{\Delta Z_{i}}
$$


Table 2: Levels and range of the variables tested in the CCD design.

\begin{tabular}{|c|c|c|c|c|c|c|c|}
\hline Variables & Factors & Unit & & \multicolumn{4}{|c|}{ Range and levels } \\
\hline & & & $\begin{array}{c}\text { Lowest } \\
-\alpha\end{array}$ & $\begin{array}{l}\text { Low } \\
-1\end{array}$ & $\begin{array}{c}\text { Center } \\
0\end{array}$ & $\begin{array}{c}\text { High } \\
+1\end{array}$ & $\begin{array}{l}\text { Highest } \\
+\alpha\end{array}$ \\
\hline $\mathrm{pH}$ & A & - & 2 & 2 & 6 & 10 & 10 \\
\hline Coagulants dosage & B & $\mathrm{mg} / \mathrm{L}$ & 200 & 200 & 600 & 1000 & 1000 \\
\hline Dye concentration & $\mathrm{C}$ & $\mathrm{mg} / \mathrm{L}$ & 20 & 20 & 60 & 100 & 100 \\
\hline Time & D & $\min$. & 60 & 60 & 300 & 540 & 540 \\
\hline
\end{tabular}

Table 3: Proximate compositions determination of the coagulant precursor

\begin{tabular}{lllllll}
\hline S/No. & Parameters & \multicolumn{5}{c}{ Values } \\
\hline & & $\begin{array}{l}\text { Vigna } \\
\text { unguiculata } \\
\text { (Cowpea) }\end{array}$ & $\begin{array}{l}\text { Telfaria } \\
\text { occidentalis } \\
\text { (fluted pumpkin } \\
\text { seed) }\end{array}$ & $\begin{array}{l}\text { Brachystegia } \\
\text { eurycoma(Black } \\
\text { timber) }\end{array}$ & $\begin{array}{l}\text { Vigna } \\
\text { subterranean } \\
\text { (Bambara nut) }\end{array}$ & $\begin{array}{l}\text { Moringa } \\
\text { oleifera } \\
\text { seed(Horse } \\
\text { radish) }\end{array}$ \\
\hline 1. & Yield & 11.5 & 38.40 & 28.31 & 14.6 & 32.68 \\
2 & Bulk density (g/mL) & 0.299 & 0.354 & 0.235 & 0.241 & 0.425 \\
3. & Moisture Content & 9.0 & 12.58 & 7.25 & 10.0 & 5.02 \\
4. & Ash content (\%) & 3.48 & 1.52 & 3.48 & 2.97 & 2.12 \\
5. & Protein content (\%) & 25.14 & 55.09 & 19.77 & 18.15 & 39.34 \\
6. & Fat content (\%) & 0.53 & 17.17 & 10.53 & 6.30 & 19.47 \\
7. & Fibre content (\%) & 6.78 & 0.87 & 2.20 & 1.64 & 1.16 \\
8. & Carbohydrate (\%) & 55.07 & 12.77 & 56.76 & 60.94 & 32.89 \\
\hline & & & & &
\end{tabular}

In (2), $\mathrm{Z}_{\mathrm{i}}$ stands for the uncoded value of ith independent variables, $Z_{i}^{*}$ stands for the uncoded value of ith independent variables at centre point and $\Delta \mathrm{Z}_{\mathrm{i}}$ is a step change value.

Design-expert software 9.0 (State Ease, Minneapolis, USA) was used for regression and graphical analysis, fitting to a second-order polynomial model to optimize the variables in the coagulation-flocculation process. Each response was used to develop an empirical model which correlated the response to the dye coagulationflocculation variables using a second degree polynomial equation as given by Eq. (4):

$$
\begin{gathered}
Y=b_{0}+\sum_{i=1}^{n} b_{i} X_{i}+\sum_{i=1}^{n} b_{i i} X_{i}^{2}+\sum_{i=1}^{n-1} \sum_{j=i+1}^{n} b_{i j} X_{i} X_{j} \\
+\varepsilon
\end{gathered}
$$

Here $\mathrm{Y}$ is the predicted response, $\mathrm{b}_{0}$ the constant coefficient, $b_{i}$ the linear coefficients, $b_{i i}$ the quadratic coefficients, $b_{i j}$ the interaction coefficient, $X_{i} X_{j}$ are the coded values of the variables, $n$ is the number of independent test variables and $\varepsilon$ is the random error. Adequacy of the proposed model is revealed using the diagnostic tool provided by analysis of variance (ANOVA). The quality of the model fit was expressed by the coefficient of determination $\left(R^{2}\right)$. The $R^{2}$ values provide a measure of how much variability in the observed response values can be explained by the experimental factors and their interactions. These analyses are done by means of Fisher's ' $F$ ' test and P- value (probability). Model terms were evaluated by the P-value with 95\% confidence level. Finally, the optimal values of the critical parameters were obtained by analyzing the counter plots and solving the regression equation. The range and levels of the experimental design is presented in Table 2.

\section{RESULTS AND DISCUSSION}

\subsection{Characterization Result}

The proximate analyses of coagulant precursors were summarized in Table 3. The moisture content values show water absorption ability of the coagulants. High crude protein contents recorded in all the precursors especially in Telfairia occidental is indicates the presence of protein, which is in agreement with the literatures that the protein contents of the precursors are cationic polypeptides [19-22]. Fibre contents present established that the precursors were organic polymer with repeating small molecules that could extend as tails and loops when dispersed in water [28]. Crude protein, moisture contents and fibre contents present, justifies the use of the plants seed powders as coagulant in this work.

\subsection{Absorption Spectra of Dye and Calibration Curve Analysis.}

Figure 2 records the electronic absorption spectra of $1000 \mathrm{mg} / \mathrm{L}$ stock solution of AR 101 in the wavelength range of $250-800 \mathrm{~nm}$. The maximum wavelength $\left(\lambda_{\max }\right)$ of AR 101 obtained was $516 \mathrm{~nm}$. The $\lambda_{\max }$ value obtained 
from the spectra analysis was in agreement with the standard value obtained in the literature. The absorbance or calibrated curve carried at different initial dye concentrations of $10-120 \mathrm{mg} / \mathrm{L}$ was obtained as shown in Fig 3. Beer-Lambert's law was obeyed in the desired concentration range following the straight line graphs obtained from the plots [29]. The result of the calibration analysis validated spectrophotometric method as the most accurate method for determining colour concentrations in aqueous solution.

\subsection{Development of Regression Model}

In order to study the combined effect of the factors, experiments were performed for different combinations

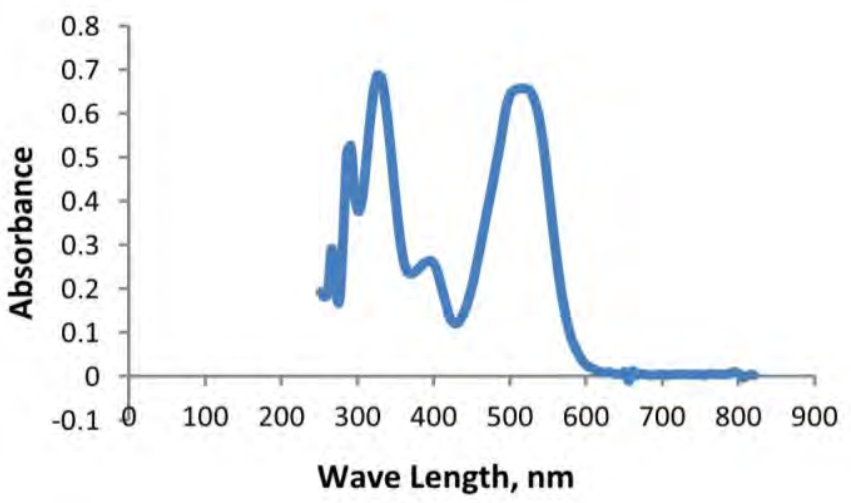

Figure 2: Spectrum Peak Pick Report for AR 101 of the parameters using statistical tool. Table 4 presented the experimental design matrix together with the experimental (exp) and predicted (pre) decolourization efficiencies for VUC (Vigna unguiculata coagulant), TOC (Telfaria occidentalis coagulant), BEC (Brachystegia eurycoma coagulant), VSC (Vigna subterranean coagulant) and MOC (Moringa oleifera coagulant). The experiment was conducted to compute the coagulationflocculation model for VUC, TOC, BEC, VSC and MOC. As a result, the responses of the colour removal efficiencies were correlated with the four independent variables $(\mathrm{pH}$, coagulant dosage, dye concentration and time), using the second-order polynomial of Eq. (4)

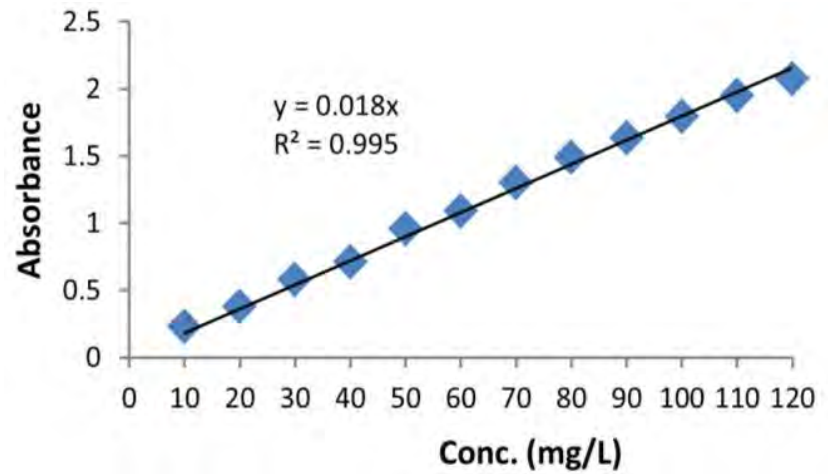

Figure 3: Calibration Curve for for AR 101 at a Wave Length $516 \mathrm{~nm}$.

Table 4: CCD in coded unit and results obtained for colour removal from $A R 101$

\begin{tabular}{|c|c|c|c|c|c|c|c|c|c|c|c|c|c|c|}
\hline \multirow{3}{*}{ Run } & \multicolumn{4}{|c|}{ Factors } & \multicolumn{10}{|c|}{ Responses } \\
\hline & $A$ & $B$ & C & D & \multicolumn{2}{|c|}{ Yvuc } & \multicolumn{2}{|c|}{ Ytoc } & \multicolumn{2}{|c|}{ Ybec } & \multicolumn{2}{|c|}{ Yvsc } & \multicolumn{2}{|c|}{ Ymoc } \\
\hline & - & $\mathrm{mg} / \mathrm{L}$ & $\mathrm{mg} / \mathrm{L}$ & $\min$ & Yexp & Ypre & Yexp & Ypre & Yexp & Ypre & Yexp & Ypre & Yexp & Ypre \\
\hline 1 & 0 & 0 & 0 & 0 & 36.9 & 37.32 & 44.3 & 17.38 & 58 & 58.42 & 55.7 & 55.70 & 50.2 & 51.15 \\
\hline 2 & 1 & 1 & -1 & -1 & 51.1 & 53.25 & 10.3 & 45.71 & 26.3 & 27.66 & 43.7 & 43.38 & 18 & 17.38 \\
\hline 3 & 1 & 1 & -1 & 1 & 82.5 & 84.32 & 35.7 & 69.33 & 55.9 & 57.74 & 73.9 & 73.94 & 47.9 & 45.71 \\
\hline 4 & 0 & 0 & 0 & 1 & 56.3 & 54.62 & 64.1 & 40.37 & 78.9 & 77.45 & 75.5 & 76.24 & 70.8 & 69.33 \\
\hline 5 & 0 & -1 & 0 & 0 & 42.7 & 38.71 & 49.3 & 28.15 & 63.5 & 64.16 & 58.7 & 59.55 & 45.1 & 40.37 \\
\hline 6 & -1 & -1 & 1 & -1 & 68.5 & 69.73 & 75.2 & 57.53 & 68.1 & 67.56 & 55.3 & 55.43 & 26 & 28.15 \\
\hline 7 & -1 & 1 & 1 & -1 & 62.3 & 64.33 & 66.4 & 38.61 & 59.4 & 62.06 & 44.2 & 44.85 & 57.7 & 57.53 \\
\hline 8 & 1 & 1 & 1 & 1 & 76.6 & 77.14 & 39.2 & 66.49 & 51 & 50.63 & 69.7 & 70.18 & 39.6 & 38.61 \\
\hline 9 & -1 & -1 & -1 & 1 & 98.7 & 87.64 & 96.7 & 51.15 & 99.2 & 103.46 & 89.9 & 89.81 & 66.1 & 66.49 \\
\hline 10 & 0 & 0 & 0 & 0 & 36.9 & 37.32 & 44.3 & 7.15 & 58 & 58.42 & 55.7 & 55.70 & 50.2 & 51.15 \\
\hline 11 & 1 & -1 & 1 & -1 & 47.2 & 49.57 & 12.9 & 12.30 & 32.9 & 33.75 & 49 & 48.45 & 8.5 & 7.15 \\
\hline 12 & 1 & -1 & -1 & -1 & 58.7 & 59.84 & 14.8 & 51.15 & 48.1 & 47.66 & 52.5 & 53.52 & 12.5 & 12.30 \\
\hline 13 & 0 & 0 & 0 & 0 & 36.9 & 37.32 & 44.3 & 40.97 & 58 & 58.42 & 55.7 & 55.70 & 50.2 & 51.15 \\
\hline 14 & 0 & 0 & 0 & -1 & 27.1 & 27.94 & 35.7 & 24.18 & 48.2 & 48.81 & 46.9 & 46.15 & 41.4 & 40.97 \\
\hline 15 & 1 & 0 & 0 & 0 & 57.4 & 56.60 & 23.3 & 51.15 & 41.7 & 43.02 & 63.3 & 63.22 & 19.5 & 24.18 \\
\hline 16 & 0 & 0 & 0 & 0 & 36.9 & 37.32 & 44.3 & 99.17 & 58 & 58.42 & 55.7 & 55.70 & 50.2 & 51.15 \\
\hline 17 & -1 & 1 & -1 & 1 & 96.1 & 90.89 & 90.4 & 51.15 & 96.3 & 94.35 & 78.5 & 78.87 & 97.3 & 99.17 \\
\hline 18 & 0 & 0 & 0 & 0 & 36.9 & 37.32 & 44.3 & 53.84 & 58 & 58.42 & 55.7 & 55.70 & 50.2 & 51.15 \\
\hline 19 & 0 & 0 & -1 & 0 & 44.8 & 44.70 & 36.6 & 38.18 & 62.1 & 62.33 & 51.9 & 52.14 & 54.8 & 53.84 \\
\hline 20 & 1 & -1 & -1 & 1 & 89.1 & 84.23 & 41.7 & 61.42 & 79.9 & 76.15 & 84.8 & 83.98 & 37.5 & 38.18 \\
\hline 21 & -1 & 0 & 0 & 0 & 70 & 69.97 & 80.8 & 11.38 & 80.4 & 78.23 & 69.1 & 69.17 & 68 & 61.42 \\
\hline 22 & 1 & 1 & 1 & -1 & 46.9 & 41.00 & 13.5 & 37.01 & 21.9 & 18.95 & 38.5 & 38.77 & 11.8 & 11.38 \\
\hline 23 & -1 & -1 & -1 & -1 & 73.8 & 70.42 & 75.7 & 67.24 & 78.6 & 77.87 & 61.7 & 61.05 & 35.5 & 37.01 \\
\hline 24 & -1 & 1 & -1 & -1 & 67.5 & 67.00 & 60.9 & 58.83 & 68 & 67.17 & 49.8 & 50.01 & 67.7 & 67.24 \\
\hline 25 & 0 & 1 & 0 & 0 & 32.9 & 36.06 & 39.9 & 56.53 & 53.7 & 52.20 & 50.1 & 49.24 & 56 & 58.83 \\
\hline 26 & -1 & -1 & 1 & 1 & 97 & 92.02 & 99.5 & 51.15 & 97.2 & 94.75 & 84.9 & 85.05 & 55.4 & 56.53 \\
\hline 27 & 0 & 0 & 0 & 0 & 36.9 & 37.32 & 44.3 & 31.93 & 58 & 58.42 & 55.7 & 55.70 & 50.2 & 51.15 \\
\hline 28 & 1 & -1 & 1 & 1 & 75.5 & 79.04 & 36.4 & 88.36 & 61.7 & 63.84 & 79.8 & 79.77 & 31.5 & 31.93 \\
\hline 29 & -1 & 1 & 1 & 1 & 91.4 & 93.30 & 95.6 & 45.86 & 89.1 & 90.84 & 75.4 & 74.56 & 88.2 & 88.36 \\
\hline 30 & 0 & 0 & 1 & 0 & 41.5 & 40.77 & 50.6 & 44.62 & 54.7 & 53.62 & 47.7 & 47.45 & 46.8 & 45.86 \\
\hline
\end{tabular}




\subsection{Analysis of Variance (ANOVA) for Response Surface Quadratic Model}

The adequacy of the model was further justified through ANOVA as shown in Table 5. The quadratic regression for colour removal efficiency shows that all the models were significant at 95\% confidence level by the Fisher's test as shown in Table 5. These were confirmed having obtained F-values of 48.72, 197.30, 131.03, 865.24 and 108.62 for VUC, TOC, BEC, VSC and MOC, respectively. In addition, the P-values for the quadratic models for the five coagulants were less than 0.05 , (P-values of regression $\leq 0.05$ ) indicating models were statistically significant. In addition, the models did not exhibit lack-of-fit indicating insignificant lack-of-fit. The lack-of-fit test measures the failure of the model to represent data in experimental domain at points that are not included in the regression. If a model is significant and not suffers from lack-of-fit, it does not necessarily mean a good one. If the experimental environment is quite noisy or some important variables are left out of the experiment, then it is possible that the portion of the variability in the data not explained by the model, also called the residual could be large [30].

Thus, a measure of the model's overall performance referred to as the coefficient of determination $\left(\mathrm{R}^{2}\right)$ must be considered. When predicted $\mathrm{R}^{2}$ and adjusted $\mathrm{R}^{2}$ differ dramatically, there is a good chance that non-significant terms have been included in the model [27]. A high $\mathrm{R}^{2}$ value, close to 1 , is desirable and ensures a satisfactory adjustment of the quadratic model to the experimental data. The $\mathrm{R}^{2}$ values of $97.85 \%, 99.46 \%, 99.19 \%, 99.88 \%$ and $99.02 \%$ for VUC, TOC, BEC, VSC and MOC indicate that the models could not explain $2.15 \%, 0.54 \%, 0.81 \%$, $0.12 \%$ and $0.98 \%$ of the total variations, respectively. The values of predicted $\mathrm{R}^{2}$ and adjusted $\mathrm{R}^{2}$ are not significantly different as shown in Table 5 . These close values of predicted $\mathrm{R}^{2}$ and adjusted $\mathrm{R}^{2}$ confirm the accuracy of the model. It was also observed from the table that for the coefficients terms such as $\mathrm{pH}(\mathrm{A})$, coagulant dosage (B), dye concentration (C) and settling time (D), whose $P<0.05$ were significant whereas some of the interaction terms $(\mathrm{AB}, \mathrm{AC}, \mathrm{AD}, \mathrm{BC}, \mathrm{BD}$ and $\mathrm{CD})$ and the square terms $\left(A^{2}, B^{2}, C^{2}\right.$ and $\left.D^{2}\right)$ were also significant to the response. Nevertheless, the interactive and square terms with P-value $>0.05$ could be considered to have no effect on the colour removal.

Positive sign in front of Eq. (5-9) indicates synergistic effect of the factors, whereas negative sign indicates antagonistic factor effect. Therefore, the overall quadratic models as expressed in Eq. (5-9) for the responses measured are significant and adequate.

Table 5: ANOVA results for the five responses: $Y_{v u c}, Y_{\text {toc }}, Y_{\text {bec }}, Y_{\text {vsc }}$ and $Y_{\text {moc. }}$

\begin{tabular}{|c|c|c|c|c|c|c|c|c|}
\hline $\mathrm{Y}_{\text {vuc }}$ & Source & $\begin{array}{l}\text { Sum of } \\
\text { Squares }\end{array}$ & $d f$ & Mean Square & F Value & $\begin{array}{l}\text { p-value } \\
\text { Prob> F }\end{array}$ & & R-Squared \\
\hline & Model & 12296.74 & 14 & 878.34 & 48.72 & $<0.0001$ & significant & \\
\hline & A-pH & 804.01 & 1 & 804.01 & 44.59 & $<0.0001$ & & \\
\hline & B-Dosage & 31.73 & 1 & 31.73 & 1.76 & 0.2045 & & \\
\hline & C-Dye Concentration & 69.62 & 1 & 69.62 & 3.86 & 0.0682 & & \\
\hline & D-Time & 3202.67 & 1 & 3202.67 & 177.63 & $<0.0001$ & & \\
\hline & $A B$ & 10.08 & 1 & 10.08 & 0.56 & 0.4662 & & \\
\hline & $A C$ & 91.68 & 1 & 91.68 & 5.09 & 0.0395 & & \\
\hline & $A D$ & 51.48 & 1 & 51.48 & 2.86 & 0.1117 & & \\
\hline & $\mathrm{BC}$ & 3.90 & 1 & 3.90 & 0.22 & 0.6485 & & \\
\hline & $\mathrm{BD}$ & 44.56 & 1 & 44.56 & 2.47 & 0.1368 & & \\
\hline & $C D$ & 25.76 & 1 & 25.76 & 1.43 & 0.2506 & & \\
\hline & $A^{\wedge} 2$ & 1746.97 & 1 & 1746.97 & 96.89 & $<0.0001$ & & \\
\hline & $\mathrm{B}^{\wedge} 2$ & 0.012 & 1 & 0.012 & $6.387 \mathrm{E}-004$ & 0.9802 & & \\
\hline & $\mathrm{C}^{\wedge} 2$ & 76.02 & 1 & 76.02 & 4.22 & 0.0579 & & \\
\hline & $D^{\wedge} 2$ & 40.77 & 1 & 40.77 & 2.26 & 0.1534 & & \\
\hline & Residual & 270.44 & 15 & 18.03 & & & & \\
\hline & Lack of Fit & 270.44 & 10 & 27.04 & & & & \\
\hline & Pure Error & 0.000 & 5 & 0.000 & & & & \\
\hline & Cor Total & 12567.19 & 29 & & & & & \\
\hline & R - Squared & & & & & & & 0.9785 \\
\hline & Adjusted R - Squared & & & & & & & 0.9584 \\
\hline & Pred R - Squared & & & & & & & 0.8276 \\
\hline
\end{tabular}

\begin{tabular}{|l|l|r|r|r|r|r|r|r|}
\hline$Y_{\text {toc }}$ & Source & $\begin{array}{r}\text { Sum of } \\
\text { Squares }\end{array}$ & $\mathrm{df}$ & $\begin{array}{r}\text { Mean } \\
\text { Square }\end{array}$ & $\begin{array}{r}\mathrm{F} \\
\text { Value }\end{array}$ & $\begin{array}{r}\mathrm{p} \text {-value } \\
\text { Prob> F }\end{array}$ & R-Squared \\
\hline & Model & 18562.09 & 14 & 1325.86 & 197.30 & $<0.0001$ & significant & \\
\hline & A-pH & 14643.31 & 1 & 14643.31 & 2179.07 & $<0.0001$ & & \\
\hline & B-Dosage & 140.56 & 1 & 140.56 & 20.92 & 0.0004 & & \\
\hline & C-Dye Concentration & 39.01 & 1 & 39.01 & 5.81 & 0.0293 & & \\
\hline & D-Time & 3039.40 & 1 & 3039.40 & 452.29 & $<0.0001$ & & \\
\hline
\end{tabular}




\begin{tabular}{|c|c|}
\hline$Y_{\text {toc }}$ & Source \\
\hline & $\mathrm{AB}$ \\
\hline & $A C$ \\
\hline & $A D$ \\
\hline & $\mathrm{BC}$ \\
\hline & $\mathrm{BD}$ \\
\hline & $C D$ \\
\hline & $\mathrm{A}^{\wedge} 2$ \\
\hline & $\mathrm{B}^{\wedge} 2$ \\
\hline & $C^{\wedge} 2$ \\
\hline & $D^{\wedge} 2$ \\
\hline & Residual \\
\hline & Lack of Fit \\
\hline & Pure Error \\
\hline & Cor Total \\
\hline & R - Squared \\
\hline & Adjusted R - Squared \\
\hline & Pred R - Squared \\
\hline
\end{tabular}

\begin{tabular}{|c|c|c|}
\hline $\begin{array}{r}\text { Sum of } \\
\text { Squares }\end{array}$ & $d f$ & $\begin{array}{l}\text { Mean } \\
\text { Square }\end{array}$ \\
\hline 44.56 & 1 & 44.56 \\
\hline 11.39 & 1 & 11.39 \\
\hline 0.39 & 1 & 0.39 \\
\hline 31.08 & 1 & 31.08 \\
\hline 12.43 & 1 & 12.43 \\
\hline $250 \mathrm{E}-004$ & 1 & $6.250 \mathrm{E}-004$ \\
\hline 121.70 & 1 & 121.70 \\
\hline 0.92 & 1 & 0.92 \\
\hline 6.60 & 1 & 6.60 \\
\hline 57.32 & 1 & 57.32 \\
\hline 100.80 & 15 & 6.72 \\
\hline 100.80 & 10 & 10.08 \\
\hline 0.000 & 5 & 0.000 \\
\hline 18662.89 & 29 & \\
\hline & & \\
\hline & & \\
\hline
\end{tabular}

\begin{tabular}{|c|c|}
\hline$F$ & $p$-value \\
\hline Value & Prob $>F$ \\
\hline 6.63 & 0.0211 \\
\hline 1.70 & 0.2126 \\
\hline 0.058 & 0.8127 \\
\hline 4.63 & 0.0482 \\
\hline 1.85 & 0.1940 \\
\hline 301E-005 & 0.9924 \\
\hline 18.11 & 0.0007 \\
\hline 0.14 & 0.7163 \\
\hline 0.98 & 0.3373 \\
\hline 8.53 & 0.0105 \\
\hline & \\
\hline & \\
\hline & \\
\hline & \\
\hline & \\
\hline & \\
\hline
\end{tabular}

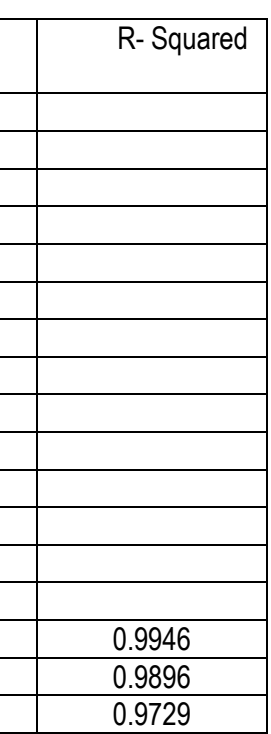

\begin{tabular}{|l|l|l|}
\hline$Y_{\text {bec }}$ & Source & \\
\hline & Model & \\
\hline & A-pH & \\
\hline & B-Dosage & \\
\hline & C-Dye Concentration & \\
\hline
\end{tabular}

\begin{tabular}{r|r|r}
$\begin{array}{r}\text { Sum of } \\
\text { Squares }\end{array}$ & df & $\begin{array}{r}\text { Mean } \\
\text { Square }\end{array}$ \\
\hline 10649.83 & 14 & 760.70 \\
\hline 5579.20 & 1 & 5579.20 \\
\hline 643.21 & 1 & 643.21 \\
\hline 341.48 & 1 & 341.48 \\
3689.41 & 1 & 3689.41 \\
\hline 86.49 & 1 & 86.49 \\
12.96 & 1 & 12.96 \\
8.41 & 1 & 8.41 \\
\hline 27.04 & 1 & 27.04 \\
2.56 & 1 & 2.56 \\
\hline 2.56 & 1 & 2.56 \\
\hline 12.63 & 1 & 12.63 \\
\hline 0.15 & 1 & 0.15 \\
\hline 0.51 & 1 & 0.51 \\
\hline 57.43 & 1 & 57.43 \\
\hline 87.09 & 15 & 5.81 \\
\hline 87.09 & 10 & 8.71 \\
\hline 0.000 & 5 & 0.000 \\
\hline 10736.91 & 29 & \\
\hline & & \\
\hline & & \\
\hline
\end{tabular}

\begin{tabular}{|c|c|}
\hline $\mathrm{Y}_{\mathrm{vsc}}$ & Source \\
\hline & Model \\
\hline & A-pH \\
\hline & B-Dosage \\
\hline & C-Dye Concentration \\
\hline & D-Time \\
\hline & $\mathrm{AB}$ \\
\hline & $A C$ \\
\hline & $A D$ \\
\hline & $\mathrm{BC}$ \\
\hline & $\mathrm{BD}$ \\
\hline & $C D$ \\
\hline & $A^{\wedge} 2$ \\
\hline & $\mathrm{B}^{\wedge} 2$ \\
\hline & $\mathrm{C}^{\wedge} 2$ \\
\hline & $D^{\wedge} 2$ \\
\hline & Residual \\
\hline & Lack of Fit \\
\hline & Pure Error \\
\hline & Cor Total \\
\hline
\end{tabular}

\begin{tabular}{r|r|r|r|r|}
$\begin{array}{r}\text { Sum of } \\
\text { Squares }\end{array}$ & df & $\begin{array}{r}\text { Mean } \\
\text { Square }\end{array}$ & $\begin{array}{r}F \\
\text { Value }\end{array}$ & $\begin{array}{r}p \text {-value } \\
\text { Prob }>\mathrm{F}\end{array}$ \\
\hline 5569.83 & 14 & 397.84 & 865.24 & $<0.0001$ \\
\hline 159.61 & 1 & 159.61 & 347.12 & $<0.0001$ \\
\hline 478.44 & 1 & 478.44 & 1040.51 & $<0.0001$ \\
98.94 & 1 & 98.94 & 215.17 & $<0.0001$ \\
4074.04 & 1 & 4074.04 & 8860.30 & $<0.0001$ \\
\hline 0.81 & 1 & 0.81 & 1.76 & 0.2043 \\
0.30 & 1 & 0.30 & 0.66 & 0.4300 \\
\hline 2.89 & 1 & 2.89 & 6.29 & 0.0242 \\
0.20 & 1 & 0.20 & 0.44 & 0.5170 \\
$1.000 \mathrm{E}-002$ & 1 & $1.000 \mathrm{E}-002$ & 0.022 & 0.8847 \\
\hline 0.72 & 1 & 0.72 & 1.57 & 0.2292 \\
285.27 & 1 & 285.27 & 620.40 & $<0.0001$ \\
\hline 4.43 & 1 & 4.43 & 9.63 & 0.0073 \\
\hline 90.40 & 1 & 90.40 & 196.61 & $<0.0001$ \\
\hline 78.18 & 1 & 78.18 & 170.02 & $<0.0001$ \\
6.90 & 15 & 0.46 & & \\
\hline 6.90 & 10 & 0.69 & & \\
\hline 0.000 & 5 & 0.000 & & \\
\hline 5576.73 & 29 & & & \\
\hline & & & & \\
\hline
\end{tabular}

\begin{tabular}{|c|c|c|}
\hline $\begin{array}{r}F \\
\text { Value }\end{array}$ & $\begin{array}{l}\text { p-value } \\
\text { Prob }>F\end{array}$ & \\
\hline 131.03 & $<0.0001$ & significant \\
\hline 960.98 & $<0.0001$ & \\
\hline 110.79 & $<0.0001$ & \\
\hline 58.82 & $<0.0001$ & \\
\hline 635.47 & $<0.0001$ & \\
\hline 14.90 & 0.0015 & \\
\hline 2.23 & 0.1559 & \\
\hline 1.45 & 0.2474 & \\
\hline 4.66 & 0.0475 & \\
\hline 0.44 & 0.5167 & \\
\hline 0.44 & 0.5167 & \\
\hline 2.18 & 0.1609 & \\
\hline 0.026 & 0.8737 & \\
\hline 0.087 & 0.7718 & \\
\hline 9.89 & 0.0067 & \\
\hline & & \\
\hline & & \\
\hline & & \\
\hline & & \\
\hline & & \\
\hline & & \\
\hline
\end{tabular}

R- Squared

C- Dye Concentration

$A C$

$A D$

$\mathrm{BD}$

CD

$\mathrm{B}^{\wedge} 2$

$\mathrm{C}^{\wedge} 2$

$\mathrm{D}^{\wedge} 2$

Cor Total

Lack of Fit

R - Squared

Adjusted R - Squared

Pred R - Squared

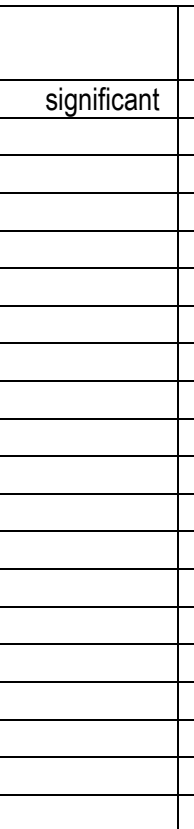

0.9919

0.9843

0.9369 


\begin{tabular}{|l|l|r|r|r|r|r|r|r|}
\hline$Y_{\text {vsc }}$ & Source & $\begin{array}{r}\text { Sum of } \\
\text { Squares }\end{array}$ & $\mathrm{df}$ & $\begin{array}{r}\text { Mean } \\
\text { Square }\end{array}$ & $\begin{array}{r}\mathrm{F} \\
\text { Value }\end{array}$ & $\begin{array}{r}\text { p-value } \\
\text { Prob> F }\end{array}$ & R-Squared \\
\hline & Adjusted R - Squared & & & & & & & 0.9976 \\
\hline & Pred R - Squared & & & & & & & 0.9917 \\
\hline
\end{tabular}

\begin{tabular}{|c|c|c|c|c|c|c|c|c|}
\hline$Y_{\text {moc }}$ & Source & $\begin{array}{r}\text { Sum of } \\
\text { Squares }\end{array}$ & df & $\begin{array}{r}\text { Mean } \\
\text { Square }\end{array}$ & $\begin{array}{r}F \\
\text { Value }\end{array}$ & $\begin{array}{r}p \text {-value } \\
\text { Prob }>F\end{array}$ & & R-Squared \\
\hline & Model & 12792.63 & 14 & 913.76 & 108.62 & $<0.0001$ & significant & \\
\hline & $\mathrm{A}-\mathrm{pH}$ & 6238.45 & 1 & 6238.45 & 741.57 & $<0.0001$ & & \\
\hline & B-Dosage & 1532.73 & 1 & 1532.73 & 182.20 & $<0.0001$ & & \\
\hline & C-Dye Concentration & 286.40 & 1 & 286.40 & 34.05 & $<0.0001$ & & \\
\hline & D-Time & 3618.17 & 1 & 3618.17 & 430.10 & $<0.0001$ & & \\
\hline & $A B$ & 632.52 & 1 & 632.52 & 75.19 & $<0.0001$ & & \\
\hline & $\mathrm{AC}$ & 13.69 & 1 & 13.69 & 1.63 & 0.2215 & & \\
\hline & $A D$ & 12.96 & 1 & 12.96 & 1.54 & 0.2336 & & \\
\hline & $\mathrm{BC}$ & 0.72 & 1 & 0.72 & 0.086 & 0.7735 & & \\
\hline & $\mathrm{BD}$ & 6.00 & 1 & 6.00 & 0.71 & 0.4115 & & \\
\hline & $C D$ & 1.21 & 1 & 1.21 & 0.14 & 0.7098 & & \\
\hline & $A^{\wedge} 2$ & 180.72 & 1 & 180.72 & 21.48 & 0.0003 & & \\
\hline & $\mathrm{B}^{\wedge} 2$ & 6.24 & 1 & 6.24 & 0.74 & 0.4027 & & \\
\hline & $C^{\wedge} 2$ & 4.39 & 1 & 4.39 & 0.52 & 0.4811 & & \\
\hline & $D^{\wedge} 2$ & 41.42 & 1 & 41.42 & 4.92 & 0.0423 & & \\
\hline & Residual & 126.19 & 15 & 8.41 & & & & \\
\hline & Lack of Fit & 126.19 & 10 & 12.62 & & & & \\
\hline & Pure Error & 0.000 & 5 & 0.000 & & & & \\
\hline & Cor Total & 12918.82 & 29 & & & & & \\
\hline & R - Squared & & & & & & & 0.9902 \\
\hline & Adjusted R - Squared & & & & & & & 0.9811 \\
\hline & Pred R - Squared & & & & & & & 0.9564 \\
\hline
\end{tabular}

Quadratic empirical models of Eq. (5-9) were obtained from experimental data for AR 101colour removal efficiency using $Y_{v u c}, Y_{\text {toc }}, Y_{\text {bec }}, Y_{v s c}$ and $Y_{\text {moc }}$ in terms of actual significant factors as:

$$
\begin{gathered}
\mathrm{Y}_{\text {Vuc }}=+113.15842-20.51107 \times \mathrm{pH}-0.015311 \times \text { Time }-0.014961 \times \mathrm{pH} \times \text { Dye Concentration }+1.62292 \\
\times \mathrm{pH}^{2} \\
\mathrm{Y}_{\text {toc }}=+97.44712-12.53123 \times \mathrm{pH}-0.016751 \times \text { Dosage }+0.13611 \times \text { Dye Concentration }+6.56448 \mathrm{E}-004 \\
\times \text { Time }+8.71094 \mathrm{E}-005 \times \text { Dosage } \times \text { Dye Concentration }+0.42834 \times \mathrm{pH}^{2}+8.16581 \mathrm{E}-005 \\
\times \text { Time }^{2}
\end{gathered}
$$

$\mathrm{Y}_{\text {bec }}=+91.74605-5.07450 \times \mathrm{pH}-0.010535 \times$ Dosage $-0.10323 \times$ Dye Concentration $+1.08096 \mathrm{E}-003$

$\times$ Time $-1.45313 \mathrm{E}-003 \times \mathrm{pH} \times$ Dosage $+8.12500 \mathrm{E}-005 \times$ Dosage $\times$ Dye Concentration

$-2.76316 \mathrm{E}-004 \times$ Dye Concentration ${ }^{2}$

$\mathrm{Y}_{\mathrm{vsc}}=+70.88597-8.88293 \times \mathrm{pH}-4.43001 \mathrm{E}-003 \times$ Dosage $+0.36840 \times$ Dye Concentration $+1.32599 \mathrm{E}$

$-003 \times$ Time $+4.42708 \mathrm{E}-004 \times \mathrm{pH} \times$ Time $+0.65581 \times \mathrm{pH}^{2}-8.16886 \mathrm{E}-006 \times$ Dosage $^{2}$

$-3.69189 \mathrm{E}-003 \times$ Dye Concentration ${ }^{2}+9.53643 \mathrm{E}-005 \times \mathrm{Time}^{2}$

$\mathrm{Y}_{\mathrm{moc}}=+20.93230+3.90184 \times \mathrm{pH}+0.057169 \times$ Dosage $-0.020216 \times$ Dye Concentration +0.020941

$\times$ Time $-3.92969 \mathrm{E}-003 \times \mathrm{pH} \times$ Dosage $-0.52198 \times \mathrm{pH}^{2}+6.94140 \mathrm{E}-005 \times \mathrm{Time}^{2}(9)$

\subsection{Model Adequacy Checking}

\subsubsection{Actual and Predicted Results of the Percentage Colour Removal.}

For a model to be reliable, the response should be predicted with a reasonable accuracy when compared with the experimental data. Figure 4 compares experimental colour removal efficiencies (\%) with the predicted values obtained from the model. The figure indicated good agreements between the experimental and predicted values. The observed points on these plots reveal that the actual values are distributed relatively near to the straight line in most cases, indicating that the regression model is able to predict these removal efficiencies. A close relationship between predicted and experimental data indicates a good fit.

\subsection{Response Surface Plotting for Evaluation of Operational Parameters}

Figures 5(a-e) shows the 3D response surface plots of quadratic models for colour removal efficiency using VUC, TOC, BEC, VSC and MOC respectively. As can be seen from Fig. $5 \mathrm{a}$, the maximum colour removal efficiency using VUC is in the region where the $\mathrm{pH}$ ranged from 2-4, 
coagulant dosage ranged from $200-400 \mathrm{mg} / \mathrm{L}$ at $60 \mathrm{mg} / \mathrm{L}$ dye concentration and time $300 \mathrm{~min}$.

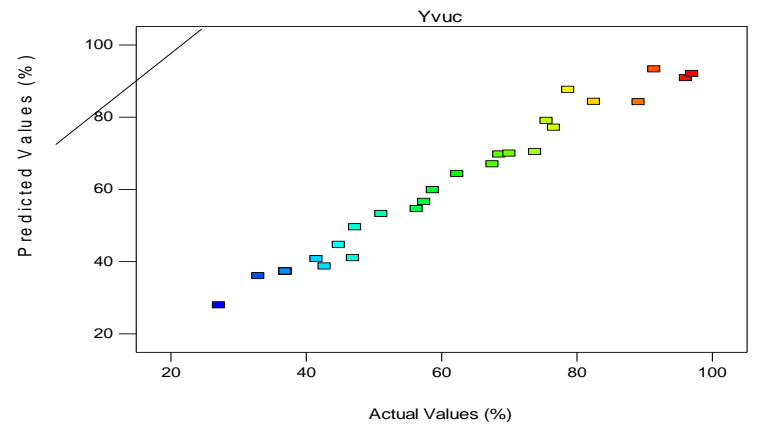

(a)

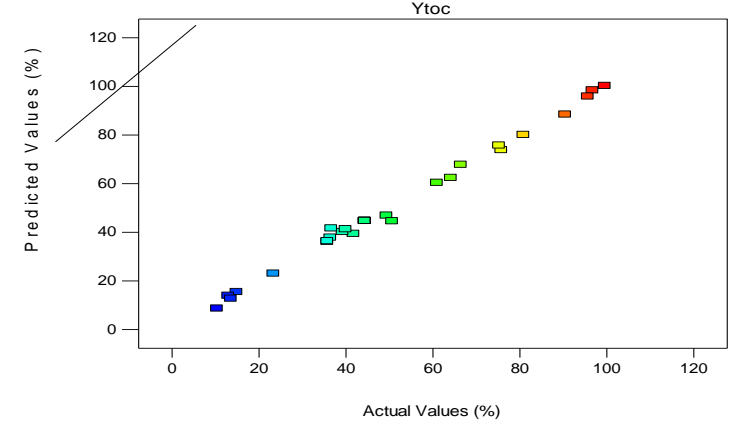

(b)

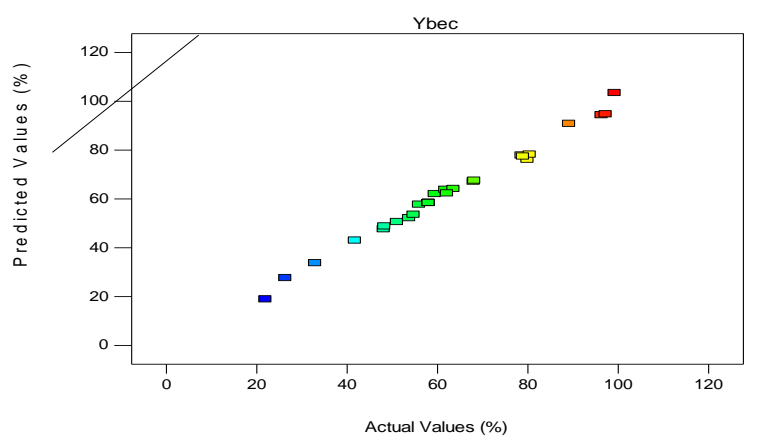

(c)

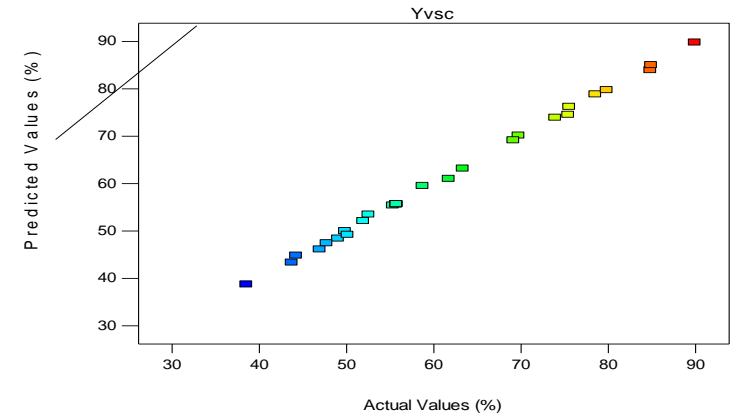

(d)

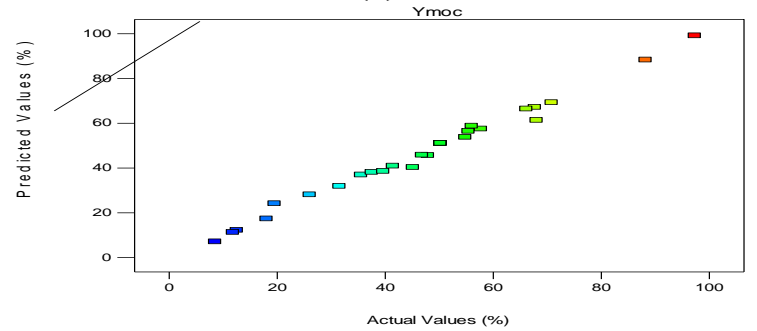

(e)

Figure 4: Parity plot for the actual and predicted values of

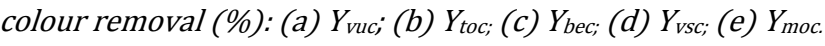

Also Fig. 5b shows that the maximum colour removal efficiency using TOC is in the region where the $\mathrm{pH}$ ranged from $2-4$, time ranged from $380-500 \mathrm{mg} / \mathrm{L}$ at $60 \mathrm{mg} / \mathrm{L}$ dye concentration and dosage $600 \mathrm{mg} / \mathrm{l}$. In addition, Fig. 5c shows that the maximum colour removal efficiency using $\mathrm{BEC}$ is in the region where the $\mathrm{pH}$ ranged from $2-4$, time ranged from $460-540 \mathrm{mg} / \mathrm{L}$ at $60 \mathrm{mg} / \mathrm{L}$ dye concentration and dosage $600 \mathrm{~m} / \mathrm{L}$. Furthermore, Fig. $5 \mathrm{~d}$ shows that the maximum colour removal efficiency using VSC is in the region where the $\mathrm{pH}$ ranged from 2-4, time from 460$540 \mathrm{~min}$ at coagulant dosage of $600 \mathrm{mg} / \mathrm{L}$ and dye concentration of $60 \mathrm{mg} / \mathrm{L}$. Lastly, Fig. 5e shows that the maximum colour removal efficiency using MOC is in the region where the $\mathrm{pH}$ ranged from $2-4$, coagulant dosage ranged from $800-1000 \mathrm{mg} / \mathrm{L}$ at $60 \mathrm{mg} / \mathrm{L}$ dye concentration and time $300 \mathrm{~min}$. In general, the response surface plots indicate that the maximum colour removal efficiencies are located inside the design boundary.

$\mathrm{pH}$ plays an important role in the coagulationflocculation process because it must be controlled in order to establish optimum conditions for coagulationflocculation. The effectiveness of the polymers in colour removal from AR 101 dye are highly dependent on $\mathrm{pH}$ as shown in Fig. 5. it was observed that the polymers showed higher colour removals at low $\mathrm{pH}$ values and maximum removal was obtained when initial $\mathrm{pH}$ of the solutions were 2 . In other words, colour removal efficiency decreased with increasing $\mathrm{pH}$. Charge on the hydrolysis products and precipitation of polymeric hydroxides are both controlled by $\mathrm{pH}$ variations [31]. As the functional groups of the acid dyes are anionic, hydrolyses products of the organic biopolymer can neutralize the negative charges on dye molecules followed by polymer adsorption.

The result illustrated in Fig. 5(a-d) indicates that with the decrease of coagulant dosages, the removal efficiencies increased and maximum colour removal efficiency was achieved at maximum coagulant dosages (200 mg/L).The high removal efficiencies of $>50 \%$ found in all the coagulants for the $200 \mathrm{mg} / \mathrm{L}$ dosages confirms that charge-neutralization and adsorption mechanism was observed to be predominant mechanism in the AR 101colour removal. Charge-neutralization followed by adsorption mechanism is the predominant mechanism at low dosages of coagulant. Positive charge species are responsible for removal of particles by charge neutralization. The use of cationic polymer for coagulation-flocculation of negatively-charged colour particles is needed, because strong adsorption affinity and neutralization of the particle charges could occur. As expected, the polymer charge density (CD) is very important; with higher CD of coagulants the optimum dosage becomes lower. It is the total amount of charge 
adsorbed that is important, rather than the polymer dosage itself.

Increase in the coagulant dosages resulted in a decrease in the removal efficiency. This trend was observed in Fig. 5 (a-d), at dosages higher than $800 \mathrm{mg} / \mathrm{l}$, when the removal efficiencies began to decrease. This implies that overdosing happened in the reaction solution. Overdosing deteriorates supernatant quality, referring to the "re-stabilization" of the colour particles and therefore the particles could not coagulate well. With excess polymer adsorption, the particle charge may be reversed. This raises the question of the role of straightforward charge effects in the destabilization and re-stabilization of negative colloids by cationic polymer. This could also be a cause of reversal on the dosages after reaching an optimum.

High removal efficiency obtained at higher dosages as shown in Fig. 5e explained the involvement of sweep flocculation and adsorption mechanisms, which are all inclined to occur at high dosages. The coagulant apparently served as condensation nuclei and the dye particles were enmeshed as the precipitate was settled. The high dosages of the organic polymer could also give rise to chain bridging and adsorption mechanism [11]. In general, charge neutralization, sweep flocculation and polymer adsorption played a predominant role in the coagulation-flocculation process due to its $\mathrm{pH}$ and dosing values. However, the acidic condition ( $\mathrm{pH} \mathrm{2-4)}$ was in favour of the improvement of cationic charge density as well as the extension of the grafting chain in the solution. This brought about the fourth mechanism "inter-particle bridging" which could be present due to high polymer dosages as observed in MOC.

Flocs formation involve both interactions of coagulant hydroxide precipitate following hydrolyses reaction and contact with particles. Coagulation-flocculation performance is usually evaluated through timedependent decrease in particle concentration [32]. This decrease in the concentration of particles coincides with the growth of aggregates. The longer coagulationflocculation time (60-540min) in this process is also a confirmation of presence of sorption mechanism. The reduction in concentration did not vary significantly after 420min from the initial stage. This shows that equilibrium can be assumed to have been achieved after $420 \mathrm{~min}$. Destabilization of the aggregate flocs could set in after this time. This was basically due to saturation of the active sites which does not allow further polymer adsorption and also prolonged settling time.

At high $\mathrm{pH}$ values which yielded low efficiencies for the colour removal studied, there is a competition between $\mathrm{OH}^{-}$and organic anions contaminants for polymer hydrolysis products. Adsorption of the natural organic contaminants (NOC) or NOC-polymer contaminant complexes onto polymer hydroxide precipitate forming at high $\mathrm{pH}$ is also limited. As $\mathrm{pH}$ increases, natural organic compounds become more negatively charged and polymer hydrolysis species become less positively charged, resulting in less adsorption propensity. For these reasons, coagulation-flocculation of NOC in wastewater is mainly performed under low $\mathrm{pH}$ conditions along with the presence of soluble cationic polymer hydrolysis species. These species react with anionic functional group son NOC to precipitate as a polymer-NOC. Conclusively, high removal efficiency at low $\mathrm{pH}$ values are predominant in organic contaminants removal from acid dyes. Similar results were reported by [33-34].

\subsection{Optimization Analysis}

In order to maximize the contaminant removal efficiencies, optimization analysis was done using Design expert 9.0 software. Process optimization searches for a combination of factor levels that simultaneously satisfy the criteria placed on each responses and factors. Numerical optimization was employed and the desired maximum goal was set for each factor and responses. These goals are combined into an overall desirability function, for effective maximization of the function. Optimal conditions and the optimization results are shown in Table 5. (a)

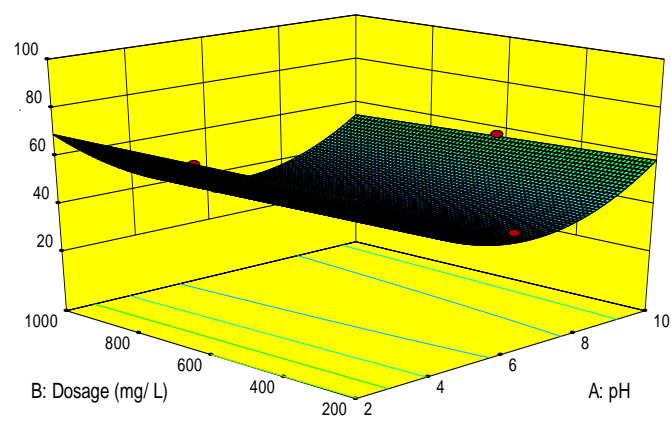

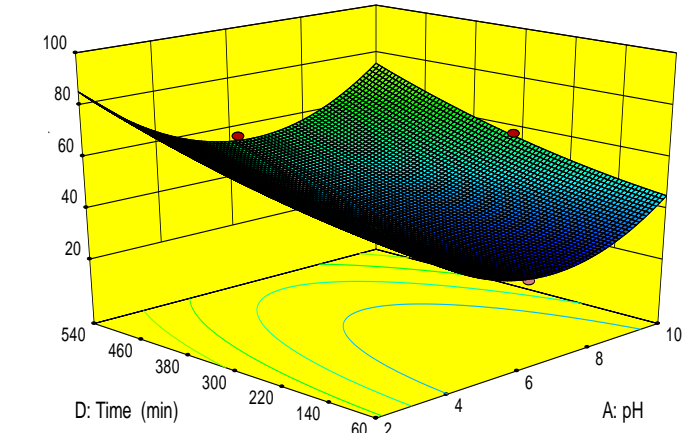


(b)

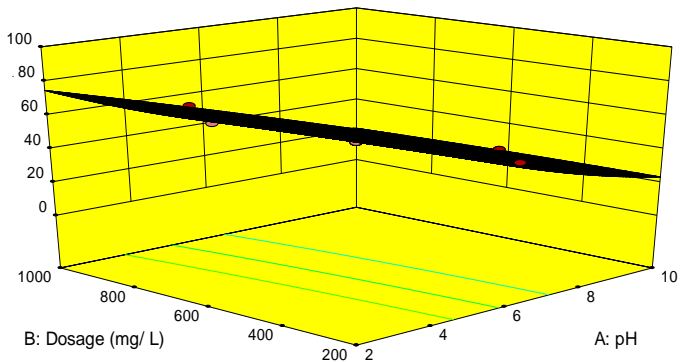

(c)

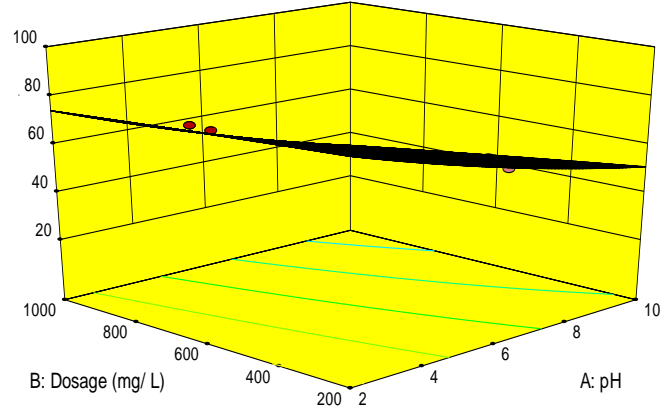

(d)

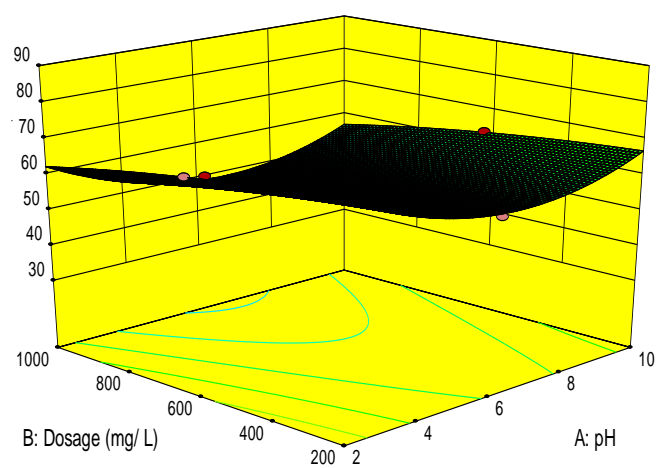

(e)

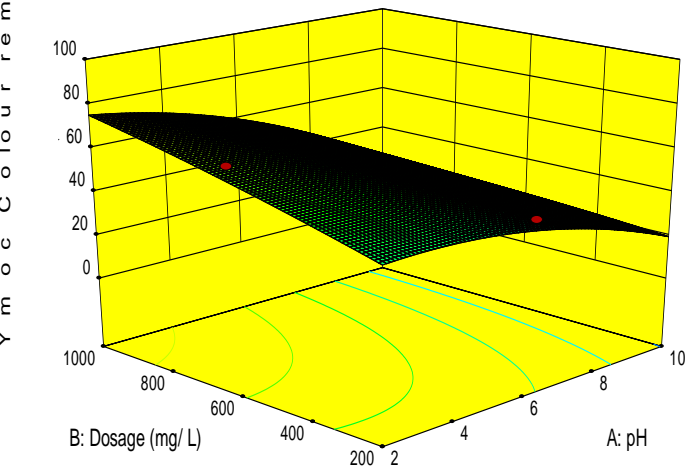

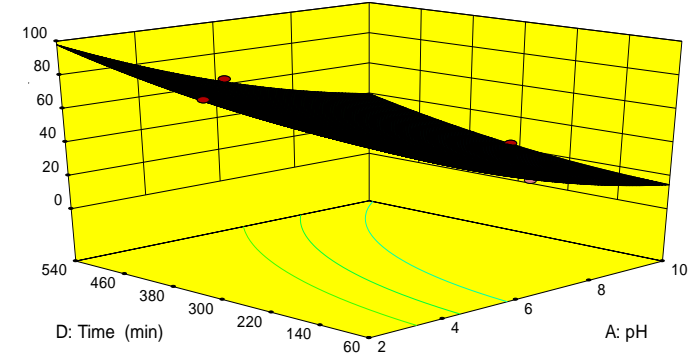

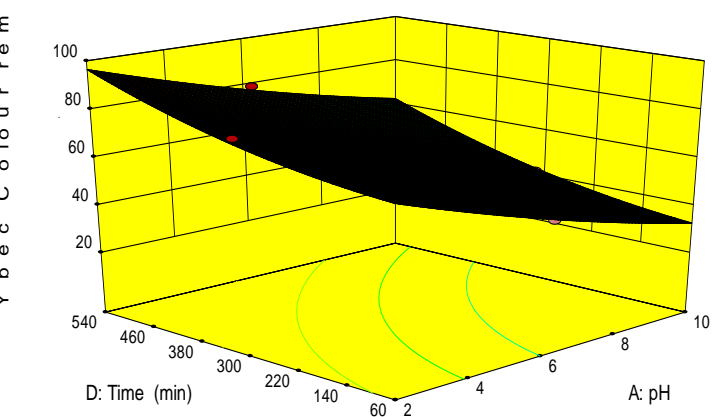

D: Time $(\min )$
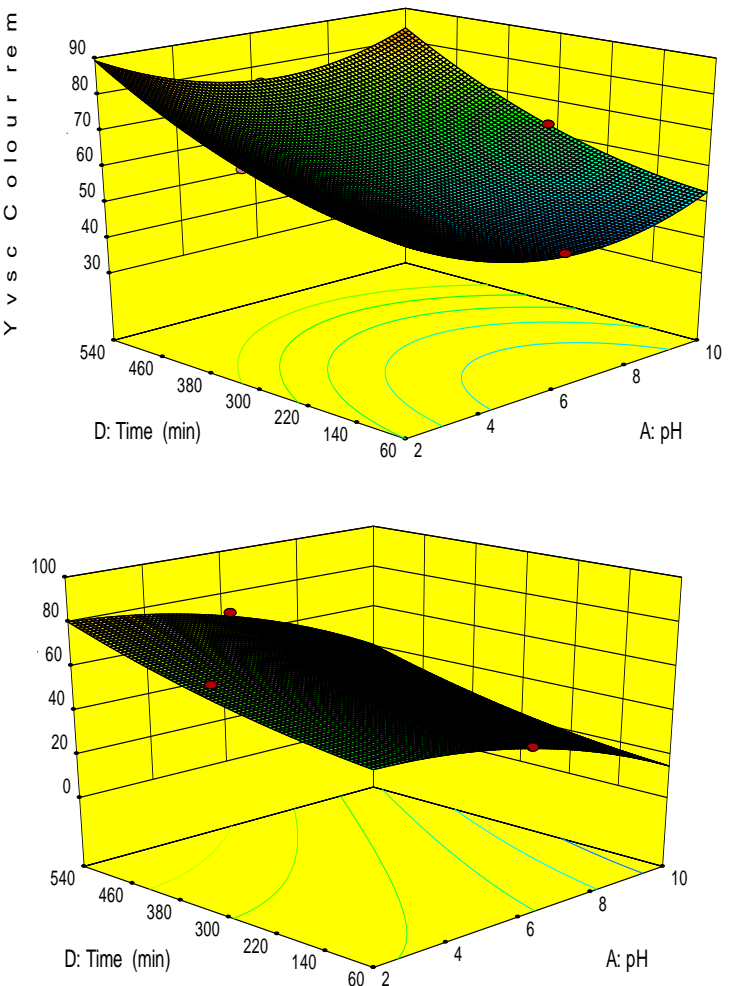

Figure 5: 3D Surface plots for colour removal as a function of: (a) $\mathrm{pH}$, dosage and time at dye concentration $60 \mathrm{mg} / \mathrm{L}$ for $\mathrm{Yvuc}_{\text {; }}$ ( (b) $\mathrm{pH}$, dosage and time at dye concentration $60 \mathrm{mg} / \mathrm{L}$ for $Y_{\text {toc; }}$ (c) $\mathrm{pH}$, dosage and time at dye concentration $60 \mathrm{mg} / \mathrm{L} \mathrm{for} \mathrm{Y}_{\text {bec; }}$ (d) pH, dosage and time at dye concentration $60 \mathrm{mg} / \mathrm{L}$ for $Y_{v s c}$; (e) $\mathrm{pH}$, dosage and time at dye concentration $60 \mathrm{mg} / \mathrm{L}$ for $Y_{\text {moc. }}$

Table 5: Confirmation analyses of the model predicted using optimum values for colour removal from dye.

\begin{tabular}{|c|c|c|c|c|c|c|c|}
\hline $\begin{array}{r}\text { Colour } \\
\text { AR } 101\end{array}$ & $\mathrm{pH}$ & $\begin{array}{l}\text { Dosage } \\
(\mathrm{mg} / \mathrm{L})\end{array}$ & $\begin{array}{c}\text { Dye Concentration } \\
\mathrm{mg} / \mathrm{L})\end{array}$ & $\begin{array}{l}\text { Time } \\
(\min )\end{array}$ & $\begin{array}{c}\text { Predicted value } \\
(\%)\end{array}$ & $\begin{array}{c}\text { Experimental value } \\
(\%)\end{array}$ & $\begin{array}{c}\text { Error } \\
(\%)\end{array}$ \\
\hline $\mathrm{Y}_{\mathrm{vuc}}$ & 2 & 265.72 & 20 & 540 & 90.74 & 89.68 & 1.17 \\
\hline$Y_{\text {toc }}$ & 2 & 437.44 & 72.84 & 540 & 99.73 & 98.24 & 1.49 \\
\hline$Y_{\text {bec }}$ & 2 & 384.66 & 20 & 540 & 99.44 & 97.54 & 2.89 \\
\hline$Y_{\mathrm{vsc}}$ & 2 & 371.29 & 70.10 & 540 & 89.92 & 87.53 & 2.66 \\
\hline$Y_{\text {moc }}$ & 2 & 998.25 & 22.65 & 540 & 98.92 & 97.15 & 1.79 \\
\hline
\end{tabular}




\subsubsection{Model validation and confirmation experiments.}

The optimum predicted values were further validated by carrying out the experiment at the optimal predicted conditions and the results of the experimental values were also shown in Table 5. The experimental checking for the optimum conditions confirms good agreements with RSM results. The verification experiments demonstrated a good agreement between the experimental and model, indicating RSM approach adopted in this study was appropriate for optimizing the coagulation-flocculation process. Also as a consequence, the maximum error (\%) between the predicted values and the experiment values were less than $4 \%$ indicating that the models adopted could predict experimental results well. The adequacy of the model was once again verified effectively by the experimental data validation

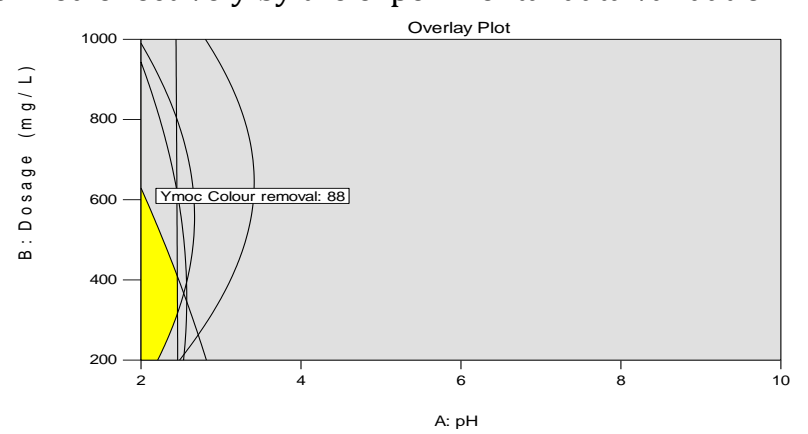

Figure 6: Overlay plots of the optimal regions for the AR 101 colour removal at optimum dye concentration of $22.65 \mathrm{mg} / \mathrm{L}$ and time of $540 \mathrm{~min}$.

\subsubsection{Multiple response optimizations (MRO)}

Removal efficiencies of the colour using VUC, TOC, BEC, VSC and MOC yielded five individual responses, and their optimizations were achieved under different optimal conditions. Thus, a compromise among the conditions for the five responses is desirable. The desirability function approach together with graphical optimization was used to achieve such goal. With multiple responses, the optimum conditions where all parameters simultaneously meet the desirable treatment level can be visualized graphically by superimposing the contours of the response in an overlay plot [24]. By defining the desired limits, the optimum condition can be visualized graphically by superimposing the contours of the five responses in an overlain plot, as shown in Fig. 6. The shaded portion of the overlay plot defined clearly the permissible values of the independent variables. Regions that do not fit the optimization criteria were shaded grey. The yellow shade ("sweet spot") satisfies the goal for every response. The values for different responses shown in Fig. 6 indicate the minimum desirable efficiency value to be overlaid. As a result, the each colour removal efficiency was optimized and the best conditions for the responses were determined. Graphical optimization of Fig 6 displays the area of feasible response values in the factor space and the regions that fit the optimization criteria was shaded yellow. Using the overlain plot for optimal region further confirms the relevance of numerical optimization done and it offers a greater flexibility in MRO [30]. Also, it is often applied when there is an emergency because it reduces preparation time and cost of experiment.

\section{CONCLUSION}

In this study, coagulation-flocculation process was optimized using VUC, TOC, BEC, VSC and MOC. The response surface methodology using face-centered central composite design was used to investigate the effect changes in the level of $\mathrm{pH}$, coagulant dosages, dye concentration and time on the percentage colour removal. The optimum combination of operating parameters that yields the maximum colour removal was determined. The results clearly showed that the colour removal efficiency was severely influenced by $\mathrm{pH}$, coagulant dosage and time. It was found that apart from the charge neutralization/adsorption which is the primary mechanism in the process, sweep-flocculation and inter-particle bridging played important roles in enhancing colour removal process. From the optimization analysis, the maximum colour removal efficiency was obtained as 90.74\%, 99.73\%, 99.44\%, $89.92 \%$ and $98.92 \%$ for VUC, TOC, BEC, VSC and MOC, respectively and the optimal conditions for optimum efficiencies were established. Generally, TOC followed by BEC were more effective in the colour removal followed by MOC and VUC. VSC was the least effective coagulant. An optimal condition of $\mathrm{pH} \mathrm{2,} \mathrm{coagulant} \mathrm{dosage}$ $375 \mathrm{mg} / \mathrm{L}$, dye concentration $22.65 \mathrm{mg} / \mathrm{L}$ and time 540min was obtained from the compromise of the five desirable responses. The confirmation experiments demonstrated a good agreement between experimental data and model values, indicating RSM approach can be successfully applied for modeling and optimizing the coagulation-flocculation process. It is an economical way of obtaining the maximum amount of information in a short period of time and with the least number of experiments.

\section{REFERENCES}

[1] Vinicius, C., Flavio, B. F., Karina, Q. D., "Treatment of textile effluent containing indigo blue dye by a UASB reactor coupled with pottery clay adsorption", ActaScientiarum Technology, vol. 35, pp. 53 - 58. 2013.

[2] Tchamango, S., Kamdoum, O., Donfack, D., Babale, D., Ngameni, E., "Comparison of electro coagulation and chemical coagulation in the treatment of 
artisanal tannery effluents", Nigerian Journal of Technology (NIJOTECH),Vol. 35, Number 1, pp. 219 $-225.2016$.

[3] Grassi, M., Kaykioglu, G., Belgiornor, V., Lofrano, G., "Removal of emerging contaminants from water and wastewater by adsorption process", Department of civil Engineering, University of Saterno, 84084 Fisciano (SA) Italy, 18 - 19. 2012.

[4] Zonoozi, M. H., Moghaddam, R. M., Arami, A. G. "Removal of Acid Red 398 dye from aqueous solutions by coagulation/flocculation process", Environmental Engineering and Management Journal, vol. 7, pp. 695 - 699. 2008.

[5] Liu, Y., Wang, J., Zheng, Y., Wang, A., “Adsorption of methylene blue by kapok fibre treated by sodium chlorite optimized with response surface methodology", Chemical Engineering Journal, vol. 184, pp. 248 - 255. 2012.

[6 Gosavi, V. D., Sharma, S. "A general review on various treatment methods for textile wastewater", Journal of Environmental Science and Technology, vol. 3, pp. 29-39. 2014.

[7] Aguilar, M. I., Saez, J., Liorens, M., Soler, A., Ortuno, J. F., "Improvement of coagulation-flocculation process using anionic polyacrylamide as coagulant aid", Chemosphere,vol. 58, pp. 47 - 56. 2005,

[8] Khouni, I., Marrot, B., Moulin, P., Amar, R. B., "Decolourization of the reconstituted textile effluent by different process treatments: Enzymatic catalysis, coagulation/flocculation and nanofiltration processes” ,Desalination, vol. 268, pp. 27 - 37. 2011.

[9] Jarvis, P., Sharp, E., Pidou, M., Molinder, R., Parsons, S. A., Jefferson, B., "Comparison of coagulation performance and floc properties using a novel zirconium coagulant against traditional ferric and alum coagulants”, Water research, vol. 46,, pp. 4179 - 4187. 2012.

[10] Tzoupanos, N. D., Zouboulis, A. I., Zhao, Y. C., "The application of novel coagulant reagent (polyaluminium silicate chloride) for the posttreatment of landfill leachates", Chemosphere, vol. 73,pp. 729 - 736. 2008.

[11] Zhu, G., Zheng, H., Chen, W., Fan, W., Zhang, P., Tshukudu, T., "Preparation of a composite coagulant: Polymeric aluminum ferric sulfate (PAFS) for wastewater treatment", Desalination, vol.285, pp. 315 - 323. 2012.

[12] Gao, B. Y., Yue, Q. Y., Wang, Y.“Coagulation performance of polyaluminum silicate chloride (PASiC) for wastewater treatment", Separation and Purification Technology, vol. 56, pp. 225 - 230. 2007.

[13] Cheng, R., Liang, S., Wang, H., Beuhler , M., "Enhanced Coagulation for Arsenic Removal",
Journal of Hazadous Material, vol. 168, 1994, pp. $155-162$.

[14] Beltrán-Heredia, J., Sánchez-Martín, J. ,"Heavy metals removal from surface water with Moringa oleifera seed extract as flocculant agent", Fresenius Environmental Bulletin, vol. 17, Number 12, pp. 2134 - 2140. 2008.

[15] Obiora-Okafo, I. A., Menkiti, M. C., Onukwuli, O. D.,"Utilization of response surface methodology and factor design in micro organic particles removal from brewery wastewater by coagulation/flocculation technique", Inter. J. of Applied Science and Maths,vol. 1, Number 1, pp. 15 - 21. 2014.

[16] Flaten, P., "Aluminum as a risk factor in Alzheimer's disease with emphasis in drinking water", Brain Res Bull, vol. 55, Number2, , pp. 187 - 196. 2001.

[17] Hassabia, Z., Madani, D., Aman, S., Hakim, L., Nabil, M., "Coagulation/flocculation test of Keddara's water dam using chitosan and sulphatealuminium", Proscenia Engineering, vol. 33, pp. 254-260 2012,.

[18] Antov, M. G., Marina, B., Petrovic, N. J., "Proteins from common bean (Phaseolus vulgaris) seed as a natural coagulant for potential application in water turbidity removal", Bioresource Technology, vol. 101, pp. 2167-2172. 2010.

[19] Mariângela, S. S. D., André, O. C., Valdirene, M. G., "Purification and molecular mass determination of a lipid transfer protein exuded from Vigna unguiculata seeds", Biological plant, vol. 44, pp. 417 - 421. 2003.

[20] Kuku, A., Etti, U. J., Ibironke, I. S., "Processing of fluted pumpkin seed, Telfairia occidentalis (Hook F) as it affects growth performance and nutrient metabolism in rats", Plant Physiolological Biochemistry, vol. 39, pp. 137 - 146. 2014.

[21] Ikegwu, O. J., Oledinmma, N. U., Nwobasi, V. N., Alaka, I. C., "Effect of processing time and some additives on the apparent viscosity of 'achi' Brachystegia eurycoma flour". Journal of food Technology, vol. 7, Number 2, pp. 34 - 37. 2009.

[22] Massawe, F. J., Mwale, S. S., Azan-Ali, S. N., Roberts, J. A., "Breeding in Bambara groundnut (Vigna subterranean): strategic considerations", African Journal of Biotechnology, vol. 4, Number 6, pp. 463 $-471.2005$.

[23] Ndabigengesere, A., Narasiah, K. S., Talbot, B. G., "Active agents and mechanism of coagulation of turbid waters using Moringa oleifera". Water Resources, vol. 29, pp. 703 - 710. 1995.

[24] Montgomery, D. C., Myers, R. H., "Response surface methodology: process and product optimization using designed experiments", 2nd ed. John Wiley and Sons, New York, 2002. 
[25] A.O.A.C., "Official Methods of Analysis", 15th Edition. Association of Official Analytical Chemists", Washington D. C, U.S.A., 1990.

[26] Okuda, T., Baes, A. U., Nishijima, W., Okada, M., "Improvement of extraction method of coagulation active components from Moringa oleifera seed", Water Resources, vol. 33 Number 15, pp. 3373 3378. 1999.

[27] Montgomery, D. C., "Design and Analysis of Experiments", 5th ed., John Wiley and Sons, New York, 2001.

[28] Bolto, B., Gregory, J. "Organic polyelectrolytes in water treatment", Water Resources, vol. 41, pp. $2301-2324.2007$.

[29] Jeffrey, G. H., Bassat, J., Mendham, J., Denney, R. C., "Textbook of quantitative chemical analysis", Fifth Edition. Longman Scientific \& Technical, pp. 649 720. 2001.

[30] Thuy, K. T, Lim, S. K., "Response surface methodological approach to optimize the coagulation-flocculation process in drinking water treatment", chemical engineering research and design, vol. 89, pp. 1126 -1135. 2011,.
[31] Li, G., Gregory, J., "Flocculation and sedimentation of high turbidity waters". Water Resources, Vol. 25, , pp. 1137 - 1143. 1991.

[32] Obiora-Okafo, I. A., Onukwuli, O. D, “Optimization of coagulation-flocculation process for colour removal from synthetic dye wastewater using natural organic polymers: Response surface methodology applied", International Journal of Scientific \& Engineering Research, vol. 6 , Number 12, ,pp. 693 704. 2015.

[33] Moghaddam, S. S., Alavi Moghaddam, M. R., Arami, M., "Coagulation/flocculation process for dye removal using sludge from water treatment plant: optimization through response surface methodology", Journal of Hazardous Materials, vol. 175 , pp. $651-657$

[34] Beltran-Heredia, J., Sanchez-Martin, J., Davila-Acedo, M. A., "Optimization of the synthesis of a new coagulant from a tannin extract", Journal of Hazardous materials, vol. 186, pp. 1704 - 1712. 2011. 